Proc. Indian Acad. Sci. (Earth Planet. Sci.), Vol. 95, No. 1, March 1986, pp. 117-130.

(C) Printed in India.

\title{
The petrology and geochemistry of massif anorthosites and gabbros of the Bavali fault zone, North Kerala
}

\author{
G R RAVINDRA KUMAR \\ Centre for Earth Science Studies, P.B. No. 2235, Trivandrum 695010, India
}

MS received 2 January 1984; revised 24 October 1985

\begin{abstract}
The massif anorthosites and gabbros occurring in the north Kerala region are localised along the Bavali fault. Several other bodies of granophyres and syenites also occupy this fault. All these bodies are considered to be a continuous graduating igneous series. This paper aims at delineating the field relations, petrochemistry and origin of massif anorthosites and gabbros occurring in the vicinity of the fault.

Anorthosites (An 70-55) are nonlayered and highly deformed with no igneous structure present. Gabbros show relict poikilitic texture with a mineralogy of plagioclase, clinopyroxene, hornblende and biotite. Geochemical study suggests dominantly calc-alkaline characteristics for both anorthosites and gabbros. However, their chemical variation is not transitional to indicate evolution by contimuous differentiation from a single parent magma. The rock types seem to be chemically unrelated and appear to have evolved independently from discreet magma sources and the magma migration might have only been promoted by the Bavali lineament.
\end{abstract}

Keywords. Anorthosite; gabbro; Bavali fault; major element; trace element; magma source; differentiation.

\section{Introduction}

The massif type anorthosites are generally of Protorozoic age (Isachaen 1969; Bridgwater and Windley 1973). The classic examples are the Adirondacks of New York State and the Nain complex of Labrador. Several bodies of massif anorthosites are known from India (De Anirudda 1969). The nature of parental magma, tectonic milieu and restricted time of emplacement of anorthosites, have become important problems to petrologists interested in the study of Precambrian crustal evolution (Wiebe 1980).

In the north Kerala region widespread occurrence of massif anorthosite, gabbro, syenite and granophyre represent important magmatic activities. They are localised along a major fault, also known as the Bavali lineament. The Bavali lineament is a westward extension of the Moyar lineament. Regular alignment of the above igneous plutons along the Bavali lineament is suggested as being due to differentiation and emplacement from a single parent magma. The geochemistry of granophyre pluton (figure 1, area 1) indicates that it is a shallow level fractionate showing a range of composition from tonalite to granite (Sinha-Roy and Ravindra Kumar 1986). Syenite (figure 2, area 2 ) is ultrapotassic $\left(\mathrm{K}_{2} \mathrm{O} \approx 13 \%\right.$ ), probably generated from peridotitic parent magma at mantle depths (Ravindra Kumar and Sinha-Roy 1986). The geochemistry of massif anorthosites and gabbros were not known. In this paper the field relations and petrochemistry of anorthosites and gabbros are presented and the nature of these relations and the possible mode of origin has been discussed. The chemistry of the gabbros of Adakkatodu (figure 1, area 4) and Kartikulam (figure 1, 


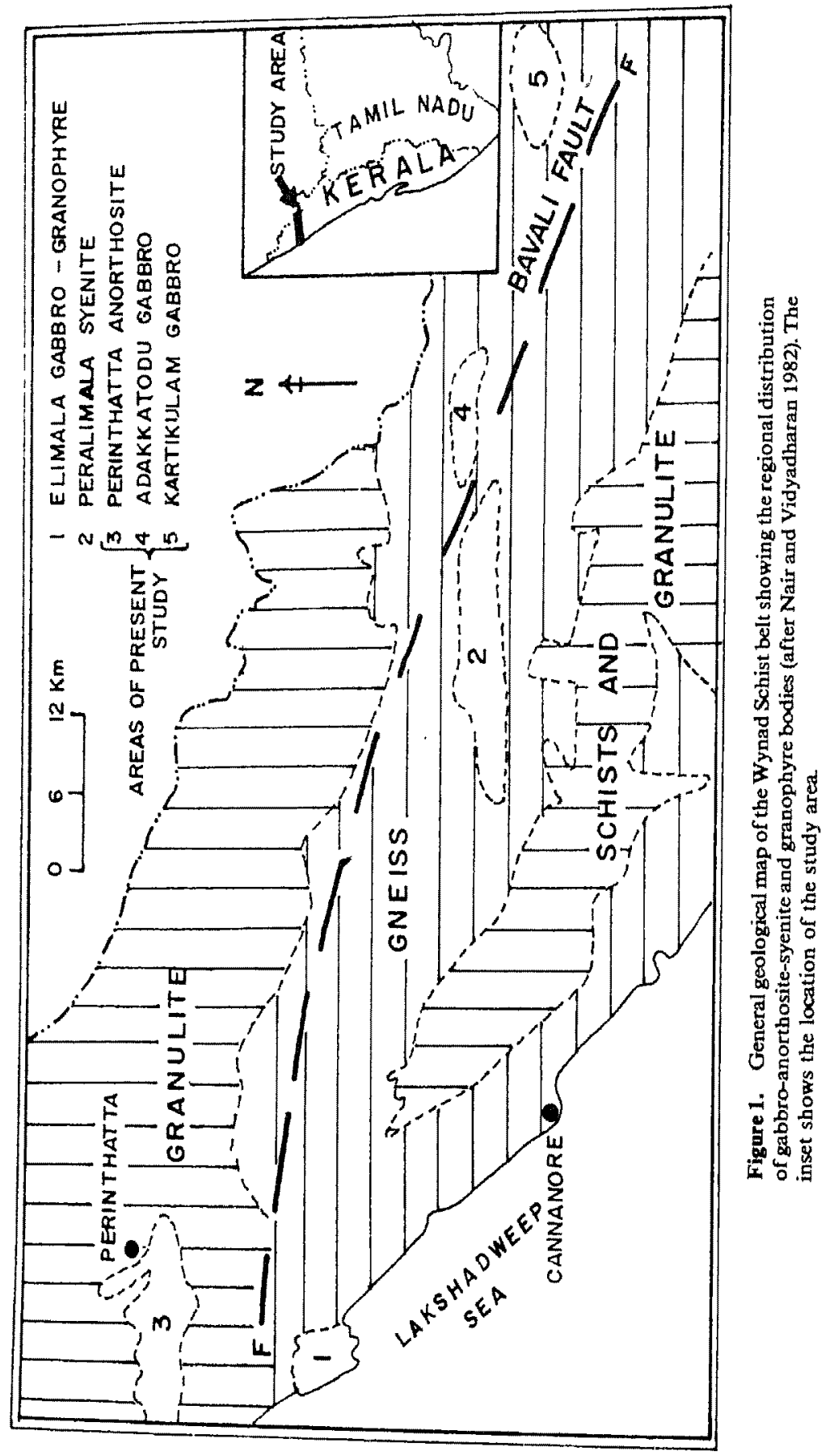


area 5) have been treated together based on similarities in field relations and petrography.

\section{Geological setting}

The anorthosite and gabbro bodies are seen within the linear Wynad belt composed of rocks of the Precambrain age. The belt has all the characteristics of a Precambrain polymetamorphic and polydeformed terrain with rock types like metasedimentaries, charnockite-granulites and a variety of gneisses. The rocks can be divided into (i) the basement group composed of migmatitic banded hornblende-biotite gneiss, (ii) shelf facies sedimentary group with quartzite-pelite, (iii) mafic and ultramafic group comprising of amphibolites and ultramafites and, (iv) igneous plutons, represented by gabbro-anorthosite-syenite-granite indicating a post-kinematic alkaline and calcalkaline magmatism. A complex of a minimum of three deformation phases have been suffered by these rock types. The mineral assemblages of the rock types reflect a varying greenschist facies to upper amphibolite facies and at places granulite facies metamorphism. This change is conspicuous from west to east of the belt.

Figure 1 gives a schematic representation of the rock types. The distribution of the gabbro-anorthosite-syenite and granophyre bodies along the fault indicates some probable control of magmatic activity in the restricted vicinity of the fault. The anorthosite body is seen to expose in rough elliptical outline to the northwest of the fault. Gabbros are exposed all along the fault, predominanting towards the east. The host rock gneisses include at places complexly deformed and metamorphosed schists. The map (figure 1) also shows the irregular outline of the anorthosite body within the granulites. Contact relations are not displayed. Extension of the anorthosites is difficult to mark due to the thick mantle of laterite. Vidyadharan et al (1977), who first identified the anorthosite body, have suggested by well section studies a total area coverage of more than $50 \mathrm{~km}^{2}$ for anorthosites.

The anorthosites are nonlayered and highly deformed with very coarse grained plagioclase laths measuring from 2 to $5 \mathrm{~cm}$. They are well exposed near Perinthatta and in adjoining areas. Recognisable primary igneous structures are not present. Plagioclase laths measuring upto $7 \times 1.5 \mathrm{~cm}$ are noticed. A crude alignment of plagioclase laths in a general E-W direction is observed. Regional dips in the surrounding rocks are observed towards the anorthosite body suggesting that the anorthosite was emplaced into a synform structure (Vidyadharan et al 1977). Several bodies of hornblendites and gabbros occur within the anorthosite massif. Field relations between these rocks and anorthosites are not clear as contacts are not preserved. Small bodies of gabbroic anorthosites and gabbro occur away from the anorthosite massif: Vidyadharan et al (1977) recorded this as a case of zonation. Anorthosites at a few places show the presence of pseudotachylyte veins. This probably suggests extreme grinding of the rock, later during deformation. In several places, tongues of anorthosites project into the granulites producing hybrid rocks in the immediate contact. Shearing is a common phenomenon in these contacts. Bands of pegmatite with predominant potassic feldspar crystals traverse the rock types in a random orientation.

The gabbro bodies occur roughly in an ellipsoidal shape, generally oriented in an $\mathrm{E}-\mathrm{W}$ direction. Though gabbros are restricted and infrequent in the close vicinity of 
anorthosite, huge plutons are seen away from the anorthosite (figure 1), measuring over $50 \mathrm{~km}^{2}$. Volume-wise gabbro dominates over anorthosite. To the west-southwest of the gabbro, a unique alkali syenite $\left(\mathrm{K}_{2} \mathrm{O} \sim 13 \%\right.$ ) (Ravindra Kumar and Sinha-Roy, 1986) is seen occupying an area of about $80 \mathrm{~km}^{2}$.

Gabbros are mainly exposed in three places, at Perinthatta and Elimala adjacent to anorthosite and granophyres bodies, along the fault around Adakkatodu, and at Kartikulam near Manantoddy. The rock is medium to coarse grained. Foliation is not very prominent but mafics are aligned in an $\mathrm{E}-\mathrm{W}$ direction. Deformation is very intense and gabbro bodies, specially close to the Bavali fault, have been extensively mylonitised. Pegmatite, quartz and pseudotachylyte veins traverse the rock generally along the weak fracture planes.

\section{Petrography}

Anorthosites are constituted by coarse crystals of plagioclase (An 70-55), minor clinopyroxene $\left(Z \Lambda C=45^{\circ} ; 2 \mathrm{Vr}=60^{\circ}\right)$, minor orthopyroxene (enstatite) and carbonates (table 1). Plagioclases are well twinned and generally the twinning is very conspicuous to the unaided eye. The plagioclases are bent, fragmented and in a few places granulated. They are randomly arranged. In the marginal zones alteration of plagioclase and carbonates is seen. Augitic clinopyroxene $\left(Z \Lambda C=45^{\circ} ; 2 \mathrm{Vr}=60^{\circ}\right)$ is dark green and feebly pleochroic from yellowish green to dark green, and biotite with shades of dark brown to yellow surround the clinopyroxene. Clinopyroxenes are also studded with magnetites. The petrographic study suggests that only plagioclase and pyroxene are primary, as evidenced by subophitic texture and zoning in feldspar, while hornblende, biotite and carbonates grew at the expenses of primary minerals.

The gabbro is characterised by the dominance of plagioclase (An 45) $(\sim 60 \%)$, clinopyroxene $\left(Z \Lambda C=38^{\circ} ; 2 \mathrm{Vr}=62^{\circ}\right)(30 \%-20 \%)$, hornblende $(10-5 \%)$ biotite $(\sim 2 \%)$ with minor magnetite $(<5 \%)$ and ilmenite(table 1$)$. A large number of samples show relict poikilitic texture. With the increase in the moddal presence of hornblende gabbro shifts towards diorite composition. A few samples show presence of garnet. surrounded by a rim is well twinned. Augitic pyroxene occurs as subhedral grains secondary origin. Occasionallys to olive green hornblendes. Hornblendes are of pyroxene and may have a primary hornblendes are seen interlocked with inclusions of plagioclase. Hornb rim of secondary yellowish green amphibole and blebs of anhedral magnetites. In cerso occurs as interstitial to plagioclase laths with quartz granules appear as fine ground deformed varieties, recrystallised secondary mafics (pyroxene/amphibole).

\section{Geochemistry}

The major and minor elements in samples from ten anorthosites, one pegmatite and ten gabbros were determined by conventional methods using usGs Syl and Sy2 as
standards. The analytical element determinations were performed to be within the range of 3-5\%. Trace Spectrometer. The chemical analyses arep on Perkin Elmer Atomic Absorption 
Table 1. Average volumetric data of seven anorthosites and eight gabbros.

\begin{tabular}{lcccccc} 
& Plagioclase & Quartz & Clinopyroxene & Hornblende & Biotite & Opaques \\
\hline $\begin{array}{l}\text { Anorthosite } \\
\text { Gabbro }\end{array}$ & 96 & - & 2 & 1 & 1 & 1 \\
\hline
\end{tabular}

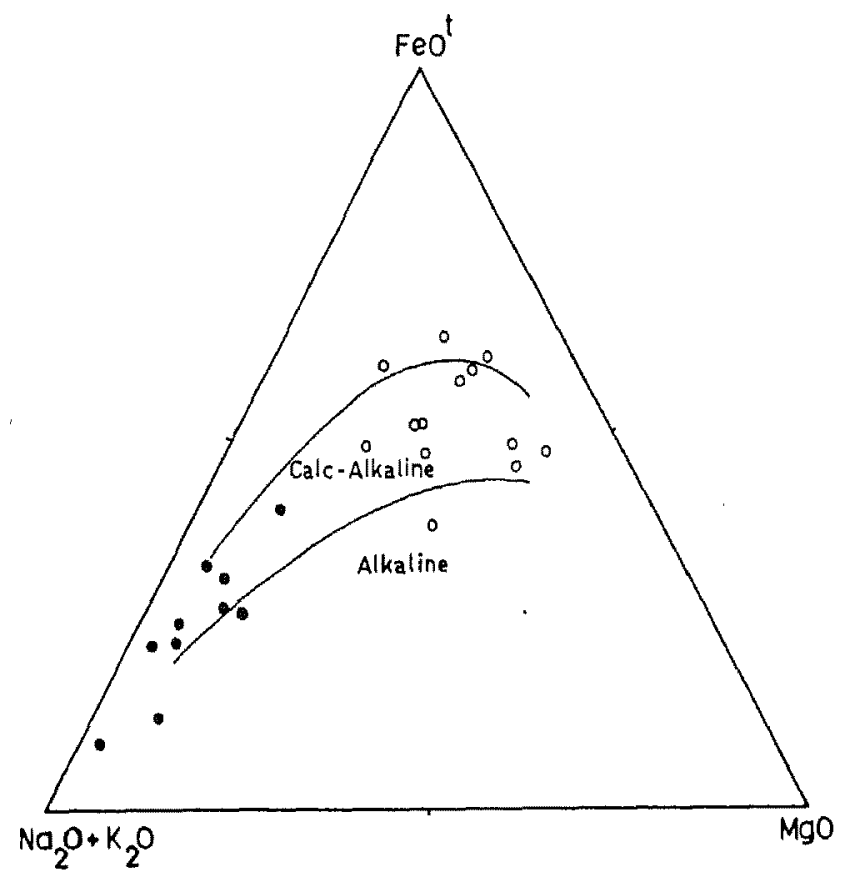

Figure 2. Triangular A-F-M projection for gabbros and anorthosites. Note the separate grouping of anorthosites and gabbros and their dominant calc-alkaline nature. Closed circles: anorthosite; open circles: gabbro.

mean major element abundances of anorthosites and gabbros are compared in table 4 with the average chemical data of other well known bodies.

The major element abundances in anorthosites and gabbros are comparable to the typical massif anorthosites (by $\mathrm{CaO} / \mathrm{Na}_{2} \mathrm{O}$ and $\mathrm{FeO} / \mathrm{MgO}$ ratios) and gabbros (cf. table 4). In anorthosites, $\mathrm{SiO}_{2}$ varies from $51.39 \%$ to $55.88 \%$, whereas in gabbros, it varies from $44.40 \%$ to $55.39 \%$. Alumina has a narrow range between $23.23 \%$ and $27.52 \%$ in anorthosites but varies from $11.73 \%$ to $18.35 \%$ in gabbros. Total alkalies $\left(\mathrm{Na}_{2} \mathrm{O}+\mathrm{K}_{2} \mathrm{O}\right)$ vary from $4.94 \%$ to $6.04 \%$ in anorthosites. An increase in total alkalies up to $12.56 \%$ is discernible towards the pegmatitic phase. In gabbros the total alkali content varies from $1.66 \%$ to $5.85 \%$. The variation of $\mathrm{CaO}(9.63$ to $12.00 \%)$ is subtle in anorthosites, whereas it varies from 6.05 to $12.10 \%$ in gabbros.

The chemical composition of the rocks clearly tend to reflect the mineralogical composition. Norms indicate that anorthosites are slightly oversaturated. Few samples are olivine normative. Among anorthosites, normative orthoclase (1-5\%), albite 


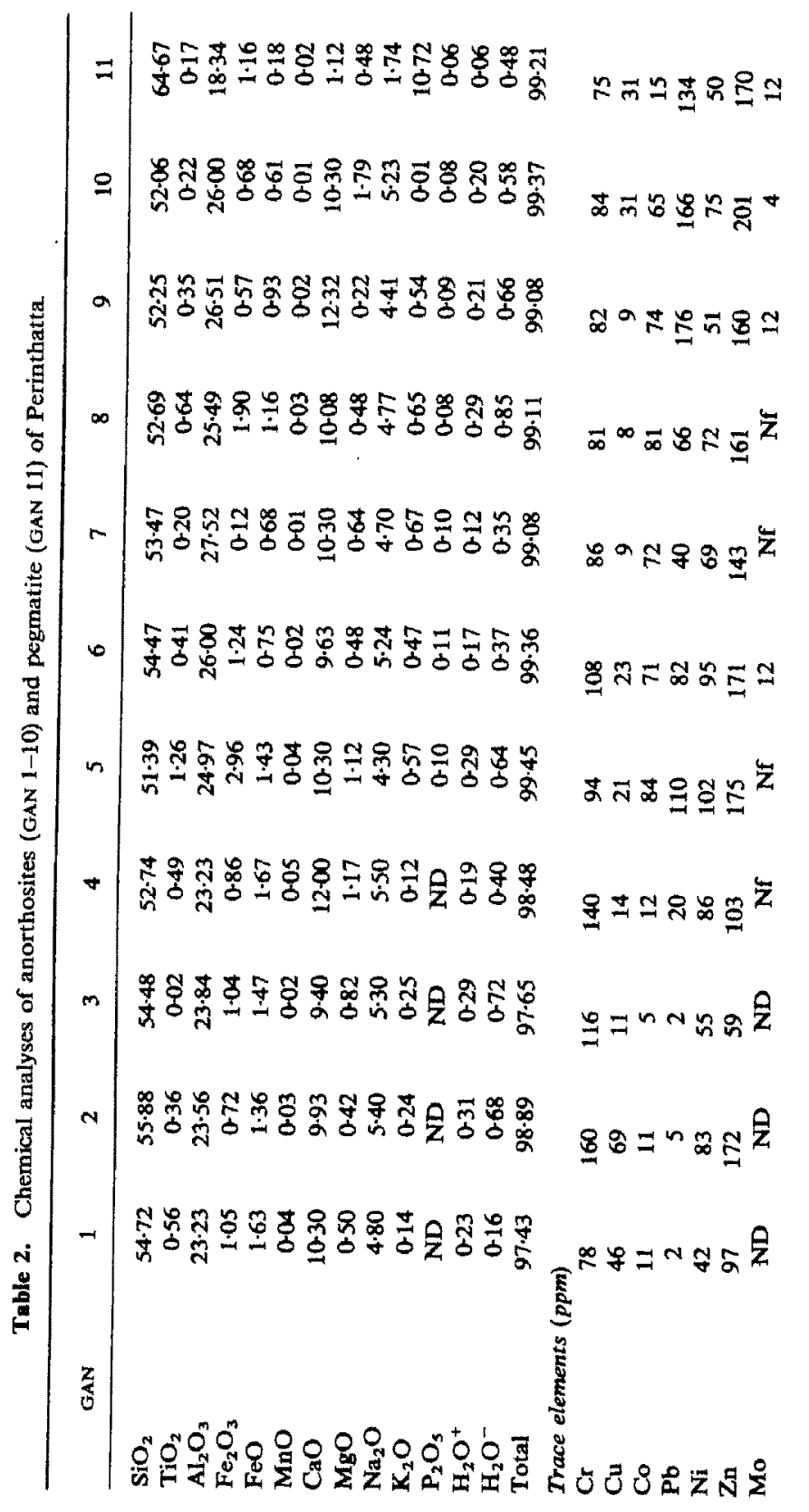




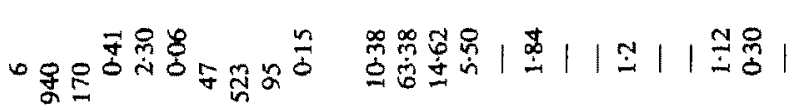

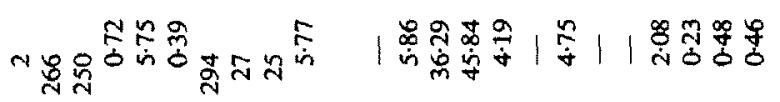

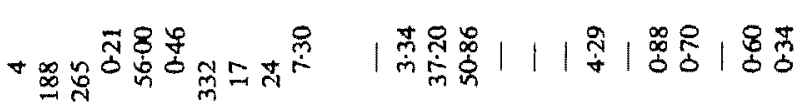

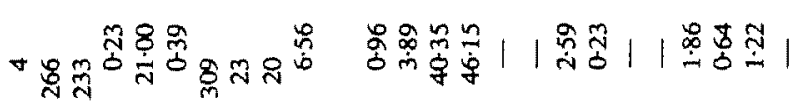

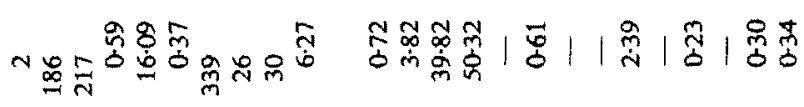

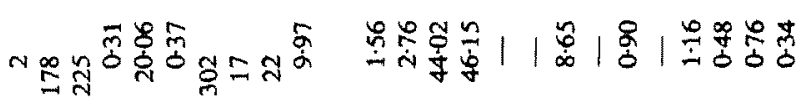

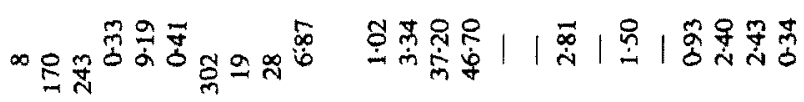

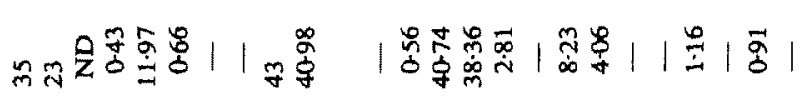

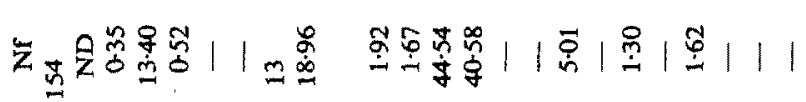

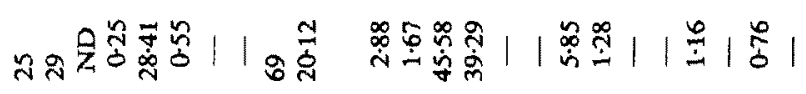

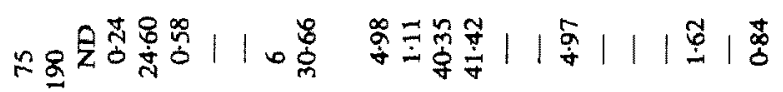

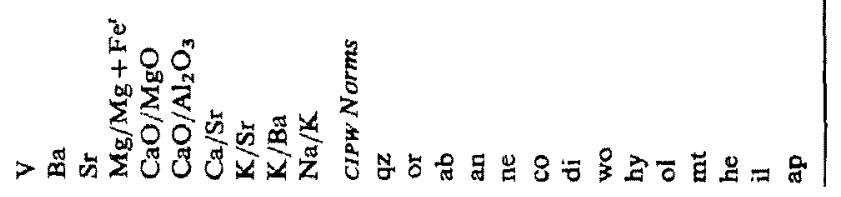




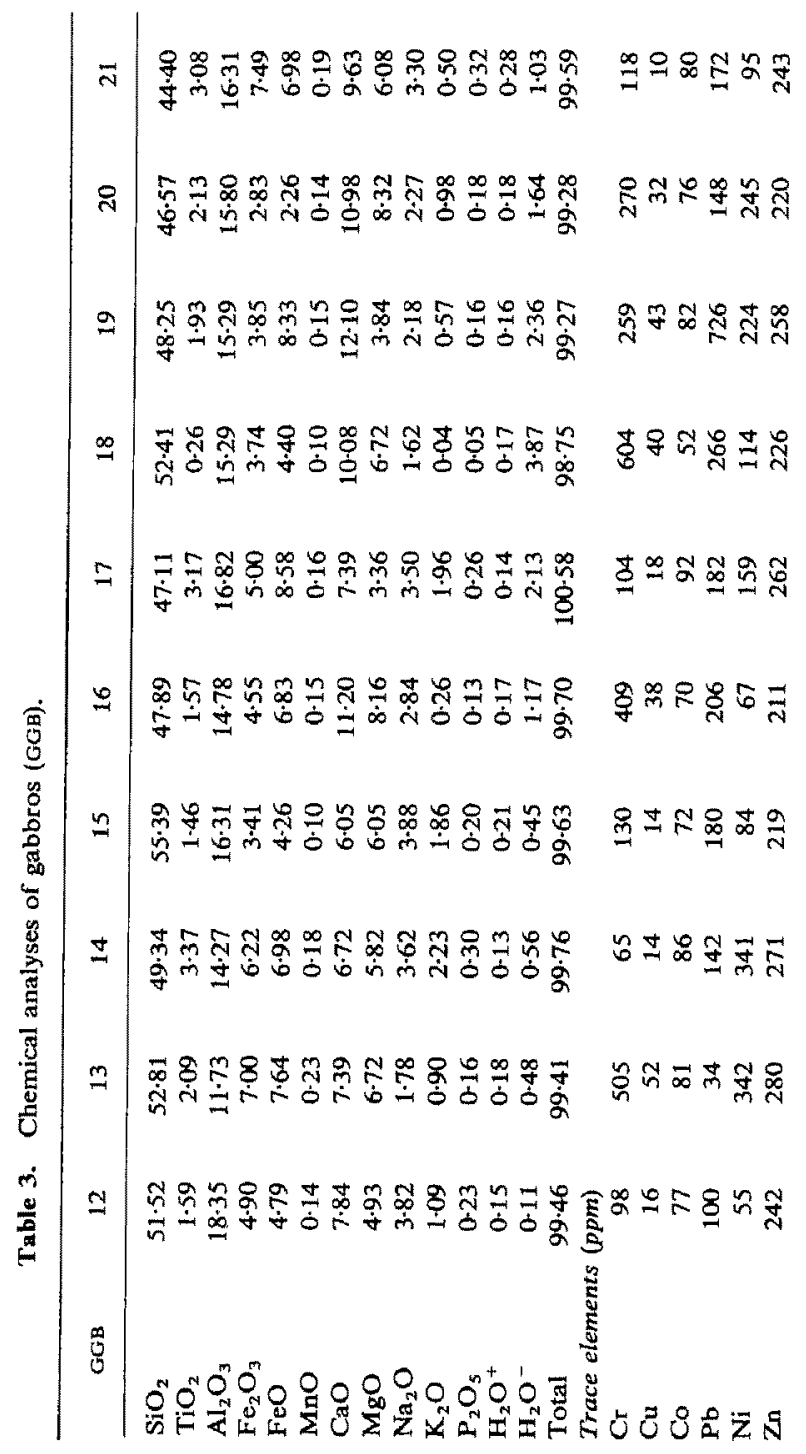




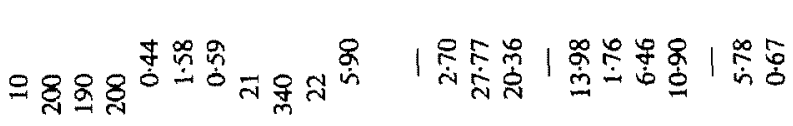

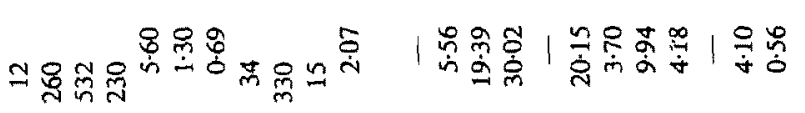

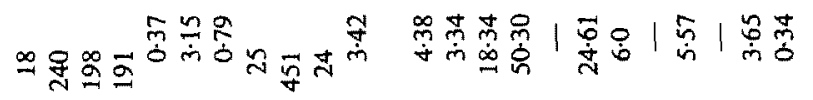

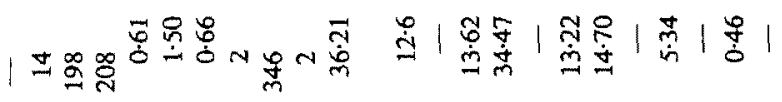

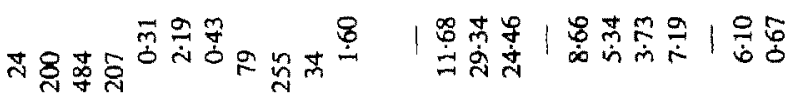

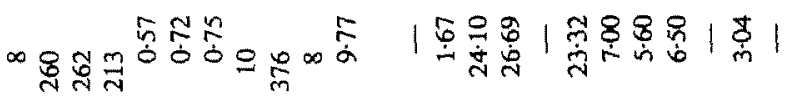

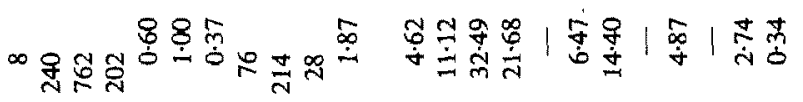

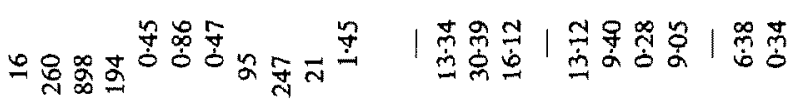

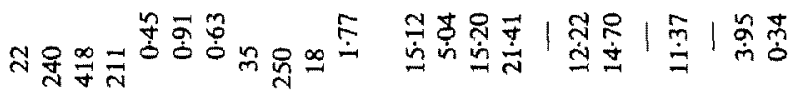

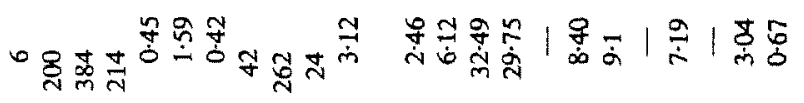

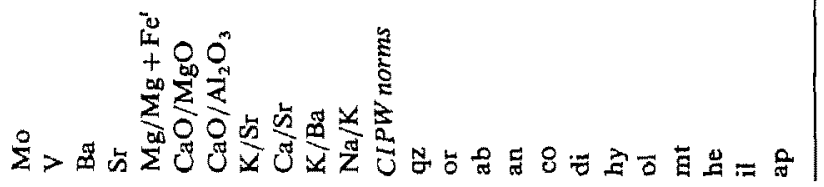


Table 4. Average compositions of anorthosites and gabbros compared.

\begin{tabular}{|c|c|c|c|c|c|c|c|c|}
\hline & 1 & 2 & 3 & 4 & 5 & 6 & 7 & 8 \\
\hline $\mathrm{SiO}_{2}$ & 44.35 & 45.87 & 48.51 & $53 \cdot 29$ & $49 \cdot 36$ & 53.52 & $48 \cdot 40$ & $49 \cdot 58$ \\
\hline $\mathrm{TiO}_{2}$ & 0.05 & 0.22 & $0-31$ & 0.34 & 0.17 & $0-45$ & 1.60 & 1.98 \\
\hline $\mathrm{Al}_{2} \mathrm{O}_{3}$ & $31 \cdot 34$ & 28.62 & 26.62 & $26 \cdot 42$ & $30-32$ & 25.03 & $16 \cdot 40$ & $15 \cdot 50$ \\
\hline $\mathrm{Fe}_{2} \mathrm{O}_{3}$ & 1.06 & 1.05 & 0.66 & $0-86$ & 0.97 & $1 \cdot 11$ & $3 \cdot 20$ & 4.98 \\
\hline $\mathrm{FeO}$ & 0.82 & 2.65 & 2.55 & 1.67 & 1.08 & $1 \cdot 17$ & $7 \cdot 40$ & $6 \cdot 10$ \\
\hline $\mathrm{MnO}$ & 0.02 & 0.06 & $0-14$ & $0-03$ & 0.11 & 0.03 & 0.17 & 0.15 \\
\hline $\mathrm{MgO}$ & $1 \cdot 12$ & 3.36 & 3.38 & 1.09 & 1.33 & 0.76 & 5.60 & 6.00 \\
\hline $\mathrm{CaO}$ & $18 \cdot 18$ & $14 \cdot 43$ & 15.21 & 10.26 & $13 \cdot 07$ & 10.46 & $9 \cdot 80$ & $8 \cdot 94$ \\
\hline $\mathrm{Na}_{2} \mathrm{O}$ & 1.22 & 1.80 & $2 \cdot 23$ & $4 \cdot 32$ & $2 \cdot 72$ & 497 & $2 \cdot 50$ & 2.88 \\
\hline $\mathrm{K}_{2} \mathrm{O}$ & 0.05 & 0.39 & 0.07 & 091 & 0.35 & 0.45 & $0-80$ & 1.03 \\
\hline $\mathrm{P}_{2} \mathrm{O}_{3}$ & 0.01 & 0.02 & 0.37 & $0-10$ & - & - & 0.21 & $0-20$ \\
\hline $\mathrm{H}_{2} \mathrm{O}$ & 0.72 & 0.53 & 0.28 & 071 & - & - & $0-70$ & - \\
\hline Total & 98.95 & 99.00 & $100 \cdot 33$ & $100-00$ & $99 \cdot 48$ & 97.95 & $96 \cdot 78$ & 97.34 \\
\hline $\mathrm{MgO} / \mathrm{FeO}$ & $0-63$ & 0.94 & 1.32 & 0.45 & 1.23 & 064 & 0.57 & 0.98 \\
\hline $\mathrm{CaO} / \mathrm{Na}_{2} \mathrm{O}$ & 14.90 & 8.02 & 6.80 & $2 \cdot 37$ & $4 \cdot 81$ & $2 \cdot 10$ & 3.92 & $3 \cdot 10$ \\
\hline
\end{tabular}

1. Average of 3 Sittampundi anorthosites (Subramaniam 1956)

2. Average of 3 Fiskenaesset anorthosites (Windley 1973)

3. Average of 18 Holenarasipur anorthosites (Naqvi and Hussain 1979)

4 Average of 48 Adirondack type anorthosite (Windley 1973)

5. Average of 4 anorthosites of Chilka Lake (Sarkar et al 1981)

6. Average of 10 Perinthatta anorthosite (present study)

7. Average of 127 analyses of gabbro (Manson 1967)

8. Average of 10 gabbro (present study).

(36-46\%) and anorthite (38-50\%) vary considerably. Normative diopside, hypersthene and olivine are present in six, four, and two samples respectively. Gabbro compositions vary from quartz $(2-19 \%)$ and hypersthene $(6-14.7 \%)$ normative ones to olivine $(0.28-9.24 \%)$ normative ones. Dominant presence of normative quartz and hypersthene in a majority of anorthosites and gabbros indicate the sub-alkaline composition of the rock types.

The sub-alkaline to calc-alkaline nature of the anorthosites and the dominantly calcalkaline to slightly tholeiitic nature of gabbros is indicated on the A-F-M diagram (figure 2). The pegmatite plots close to the alkali apex. Two plots of anorthosites cross the calc-alkaline and alkaline dividing line of Irivine and Baragar (1971). Gabbros plot distinctly away from anorthosites and tend to show the presence of a range of chemistry from calc-alkaline to tholeiitic. However, a majority are essentially calc-alkaline. No clear fractionation trend is seen between anorthosites and gabbros. Similar features are demonstrated by gabbros while plotting on $\mathrm{Na}_{2} \mathrm{O}+\mathrm{K}_{2} \mathrm{O}$ vs $\mathrm{SiO}_{2}$ diagram (figure 3). The majority of the gabbros plot in the sub-alkaline field but close to the alkaline boundary and fall close to the fields of alkali rock series and high alumina basalt series of Kuno (1966).

To summarise further the characteristics of the composition of anorthosites and gabbros, they have been plotted on $\mathrm{K}_{2} \mathrm{O}-\mathrm{Na}_{2} \mathrm{O}-\mathrm{CaO}$ diagram (figure 4). Anorthosites cluster close to calcium and show less variation with respect to alkalies indicating dominant participation of plagioclase in anorthosite. Only slight migration of gabbro towards $\mathrm{K}_{2} \mathrm{O}$ apex following calc-alkaline-tholeiitic boundary is observed. The 


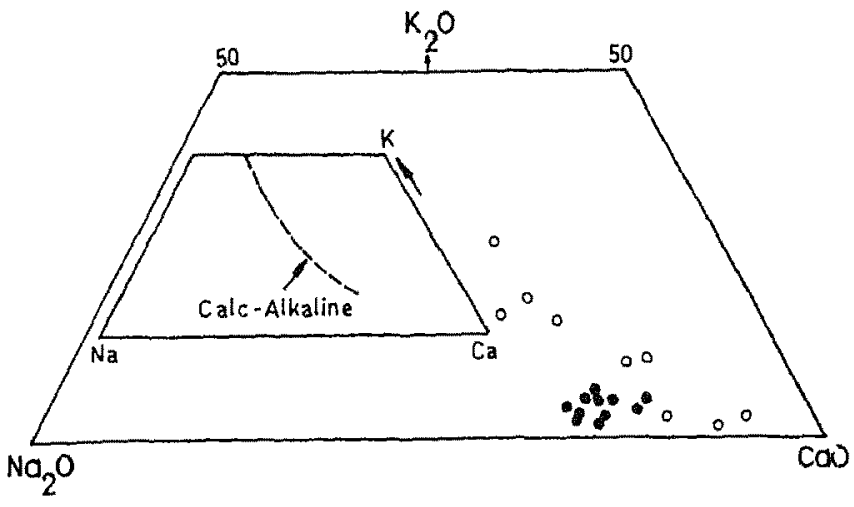

Figure 3. Plot of compositions of gabbro and anorthosite on $\mathrm{K}_{2} \mathrm{O}-\mathrm{Na}_{2} \mathrm{O}-\mathrm{CaO}$ variation diagram. Key as in figure 2. Calc-alkaline trend after Barker and Arth (1976).

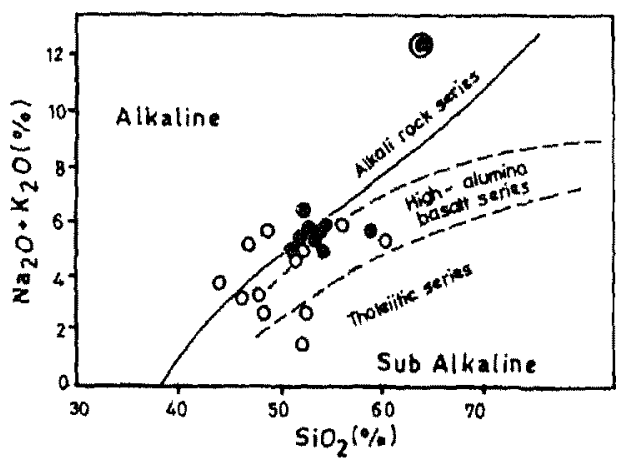

Figure 4. Total alkali versus silica diagram to distinguish alkaline and subalkaline groups (after Irivine and Baragar 1971). Fields of Kuno (1966) for alkali, high alumina basalt and tholeiite series are also shown. Symbols are as in figure 2.

diagram further illustrates that $\mathrm{K}$-feldspar played no role in anorthosites and a very limited role, probably related to deformation and migmatisation, in gabbros.

Major and trace element variations in relation to $\mathrm{Mg}$ number $\left(\mathrm{Mg} / \mathrm{Mg}+\mathrm{Fe}^{\mathrm{t}}\right)$ are presented in figure 5. It is possible to identify highly fractionated ones with lower $\mathrm{Mg}$ numbers of less than thirty, and also less fractionated ones with higher $\mathrm{Mg}$ numbers of sixty in anorthosites and gabbros. The chemistry shows a $\mathrm{Mg} / \mathrm{Mg}+\mathrm{Fe}^{1}$ ratio averaging around 0.36 for anorthosites and 0.48 for gabbros. Anorthosites and gabbros generally depict different trends of variations for all oxides against $\mathrm{Mg} / \mathrm{Mg}+\mathrm{Fe}^{\mathrm{t}}$.ratio (figure 5), and do not seem to be chemically related to each other. Except for $\mathrm{K}_{2} \mathrm{O}$, a generally smooth variation is observed for all the major oxides. $\mathrm{A}$ decrease of $\mathrm{Al}_{2} \mathrm{O}_{3}, \mathrm{TiO}_{2}$ and $\mathrm{FeO}^{t}$ is observed with increase in $\mathrm{Mg} / \mathrm{Mg}+\mathrm{Fe}^{t}$. Fractionation of plagioclase and clinopyroxene in anorthosite and in addition, orthopyroxene and magnetite in the gabbros is indicated by the diagram.

In comparison to the trace element content of Chilka Lake anorthosite $(\mathrm{V}=124 \mathrm{ppm}, \mathrm{pb}<25 \mathrm{ppm}, \mathrm{Cr}=64 \mathrm{ppm}, \mathrm{Co}<10 \mathrm{ppm}$; Sarkar et al 1981), the Perinthatta anorthosites are depleted in $\mathrm{V}$ and enriched in $\mathrm{Pb}, \mathrm{Cr}$ and $\mathrm{Co}$. This feature 


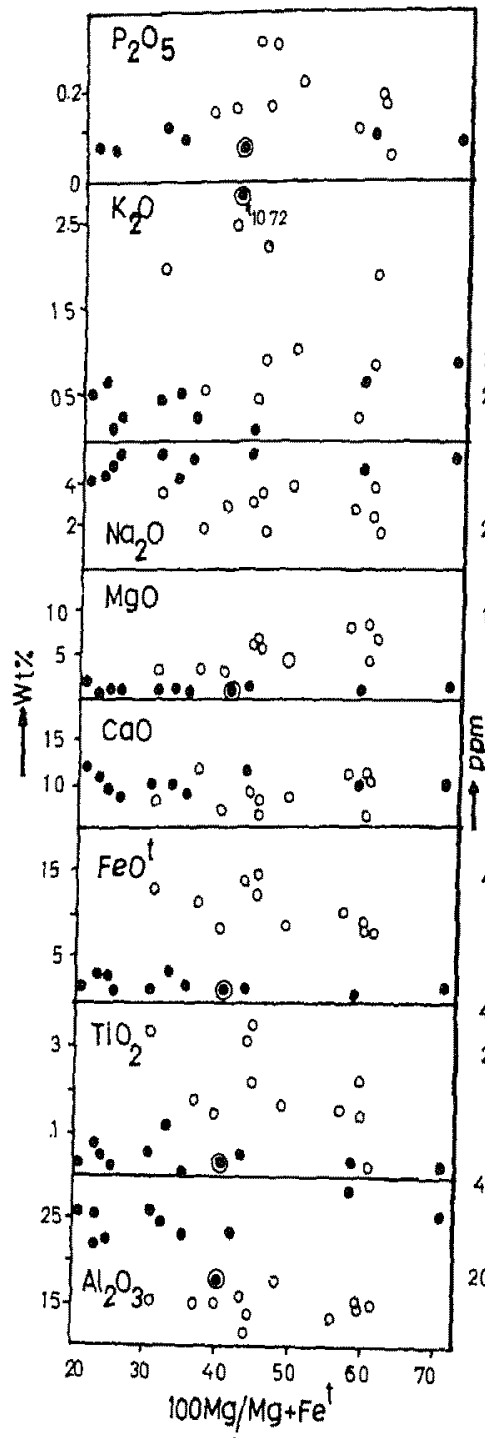

(a)

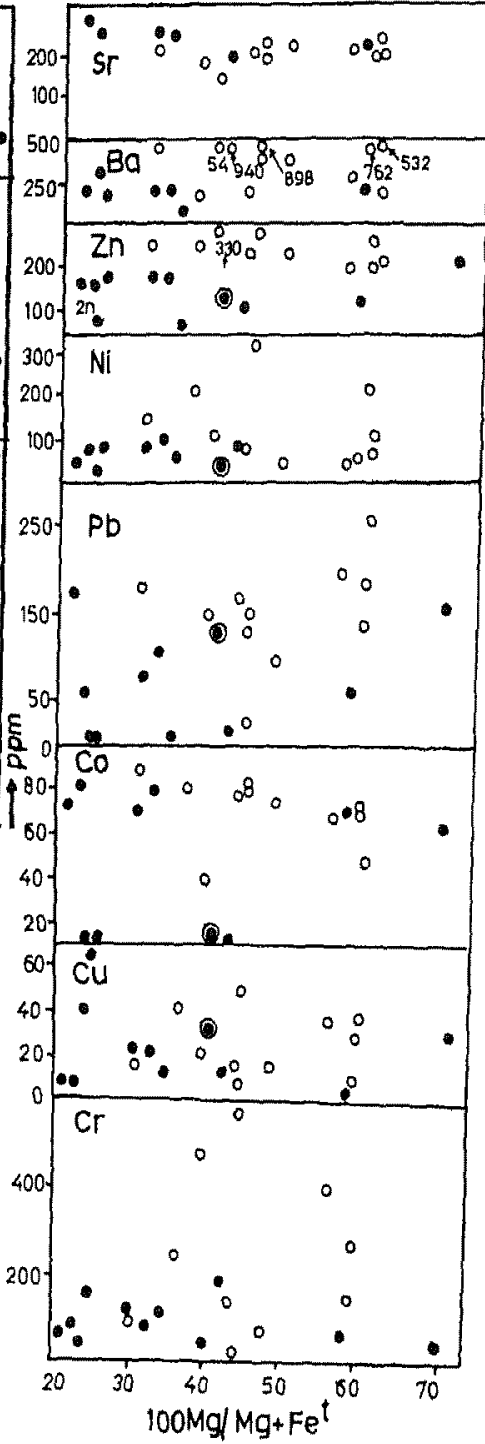

(b)

Figure 5. Major (a) and trace element (b) variations with $\mathrm{Mg} / \mathrm{Mg}+\mathrm{Fe}$. Symbols are as in figure 2.

may perhaps reflect the differences in the abundance of mafic mineralogy between the two massifs as $\mathrm{Pb}, \mathrm{Cr}$ and $\mathrm{Co}$ partition in them. The decrease in $\mathrm{V}$ content of anorthosite (average $16 \mathrm{ppm}$ ) compared to Chilka Lake anorthosites may be explained by the early separation of the clinopyroxene of the Perinthatta anorthosite at higher temperature, as V will preferentially partition in clinopyroxene only at lower temperatures (Duke 1976). Ba content increases towards the higher feldspathic end of anorthosites. $\mathrm{K} / \mathrm{Ba}$ also behaves coherently from the higher mafic end to the feldspathic 
end. The Sr content does not show any significant variation $(217-265 \mathrm{ppm})$ in anorthosite whereas a slight variation (172-230) is observed in gabbros.

\section{Conclusions}

In view of studying chemical characteristics of anorthosites and gabbros and to identify possible petrological relations, indicating any continuum in basic magmatic activity, field and geochemical studies were carried out. In many areas field and geochemical studies have indicated gabbroic parentage for anorthosites (Morse 1982). The presence of subhedral crystals of plagioclase in anorthosite suggested that the plagioclases were formed in a relatively calm environment, at depth. Chemistry indicated the calc-alkaline composition of anorthosites and gabbros. The low $\mathrm{K}_{2} \mathrm{O}$ content, cumulate plagioclase and the mafics in anorthosite are in favour of a deep environment of origin. This point also disproved the crustal anatexis for the origin of anorthosites and favours the present general consensus that anorthosites are mantle derivatives (Morse 1982).

The geochemistry of anorthosite and gabbro indicate that there is no petrogenetic continuum between anorthosites and gabbros. The absence of continuous smooth variation in several major oxides of the two rocks and presence of different trends of variation further suggests that they might have evolved from discreet magma sources. The ratios of lower $\mathrm{Mg} / \mathrm{Mg}+\mathrm{Fe}^{t}, \mathrm{CaO} / \mathrm{Na}_{2} \mathrm{O}$ and higher $\mathrm{Sr}$ content of anorthosites supports the derivation of anorthosite from plagioclase rich parent magma. The chemical features of anorthosites are also in contrast to Archaean layered anorthosites, which have higher ratios of $\mathrm{Mg} / \mathrm{Mg}+\mathrm{Fe}^{\prime}, \mathrm{CaO} / \mathrm{Na}_{2} \mathrm{O}$ and lower content of $\mathrm{Sr}$ $(50-100 \mathrm{ppm})$, suggesting derivation from ultrabasic magma. Invoking the presence of alkaline feldspathic magma as parental may serve to explain the absence of genetically related ultramafic and mafic rock associates with anorthosites and partly the evolution of highly alkaline syenite of Peralimala. Gabbros are presumably derived from a magma of basaltic composition. The regional chemical variations suggest the formation of at least three different magma types, at different levels in the crust and mantle, during the Proterozoic period (Ravindra Kumar 1984).

\section{Acknowledgements}

The author is indebted to the Director for encouragement. Sincere thanks are to Dr S K Ghosh for extending support and to Prof. A S Janardhan, University of Mysore for suggestions. Smt. Omana is thanked for technical assistance.

\section{References}

Barker F and Arth J G 1976 Geology 4596

Bridgwater D and Windley B F 1973 Geol. Soc. South Africa (Spec. Publ.) 3307

De Anirudda 1969 N. Y. State Mus. Sci. Serv. Mem. 18425

Duke J M 1976 J. Petrol. 17499

Irivine T N and Bargar W R 1971 Can. J. Earth Sci. 8523

Isachaen Y W 1969 N. Y. State Mus. Sci. Serv. Mem. 18435

Kuno H 1966 Bull. Volcanol. 29196 
Manson V 1967 in Basalts-the Poldervaart treatise on rocks of basaltic composition (New York: Inter Science)

Morse 1982 Am. Mineral. 671087

Nair M M and Vidyadharan K T 1982 J. Geol. Soc. India 2346

Naqui S M and Hussain S M 1979 Can. J. Earth Sci. 161254

Ravindra Kumar G R 1984 Abstract IGC, Moscow

Ravindra Kumar G R and Sinha-Roy S 1986 Indian mineral.

Sarkar A, Bhanumati L and Balasubramanyam MN 1981 Lithos 1493

Sinha-Roy S and Ravindra Kumar G R 1986 J. Geol. Soc. India

Subramaniam A P 1956 Geol. Soc. Am Bull. 67317

Vidyadharan K T, Sukumaran P V and Nair M M 1977 J. Geol. Soc, India 18519

Wiebe A R 1980 Nature (London) 286564

Windley B F 1973 Geol. Soc. Aust. (Spec. Publ.) 3319 